\title{
Heart Failure, CTCAE
}

National Cancer Institute

\section{Source}

National Cancer Institute. Heart Failure, CT CAE. NCI Thesaurus. Code C143529.

A disorder characterized by the inability of the heart to pump blood at an adequate

volume to meet tissue metabolic requirements, or, the ability to do so only at an elevation in the filling pressure. 